
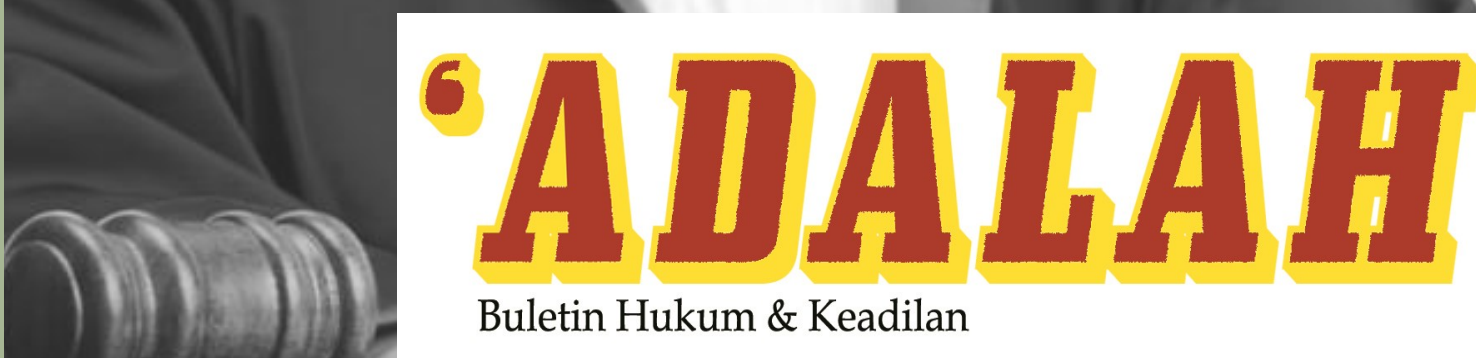

Buletin Hukum \& Keadilan

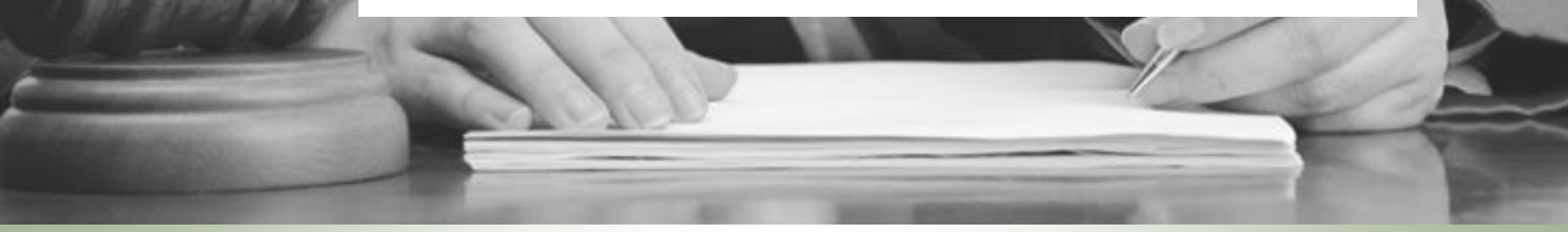

\title{
Penguatan Komisi Pemberantasan Korupsi Secara Kelembagaan Dengan Meletakkan Konstitusi Sebagai Dasar Legitimasi
}

\author{
Rayhan Naufaldi Hidayat \\ Universitas Islam Negeri Syarif Hidayatullah Jakarta \\ do \\ $\underline{10.15408 / a d a l a h . v 4 i 3.17830}$
}

Abstract:

Corruption is an extraordinary crime committed by intellectual actors by abusing their assets and positions on their hands. This crime has become a fundamental problem in the state which has not been completely resolved from year to year. One of the main factors of this is the lack of performance of the Corruption Eradication Commission (KPK) in investigating corruption cases that occur in Indonesia. Various revisions to the law that serves as a basis for legitimacy for the KPK in carrying out its duties, mains and functions are the main obstacles that the institution often faces. Therefore, one of the rational efforts that can be made by the state is to make the constitution as a rigid legitimacy basis for the KPK to provide legal certainty.

Keyword: Corruption Eradication Commission; Constitution; Legitimacy Basis

\section{Abstrak:}

Korupsi adalah kejahatan luar biasa yang dilakukan oleh aktor intelektual dengan menyalahgunakan harta dan jabatan yang ada di tangan mereka. Kejahatan tersebut menjadi persoalan mendasar di dalam negeri yang tidak terselesaikan secara tuntas dari tahun ke tahun. Salah satu faktor utama dari hal tersebut ialah ketidakoptimalan kinerja Komisi Pemberantasan Korupsi (KPK) dalam mengusut kasus-kasus korupsi yang terjadi Di Indonesia. Berbagai perubahan terhadap undang-undang yang berfungsi sebagai dasar legitimasi bagi KPK dalam menjalankan tugas, pokok, dan fungsinya menjadi kendala utama yang kerap kali dihadapi oleh lembaga tersebut. Oleh karena itu, salah satu upaya rasional yang dapat dilakukan oleh negara ialah dengan menjadikan konstitusi sebagai dasar legitimasi yang bersifat rijid bagi KPK guna memberikan kepastian hukum.

Kata Kunci: Komisi Pemberantasan Korupsi, Konstitusi, Dasar Legitimasi 


\section{Prolog}

Korupsi merupakan salah satu kejahatan luar biasa (extra ordinary crime) yang menjadi permasalahan mendasar bagi negara Indonesia. Sasaran utama dari kejahatan tersebut pada umumnya ialah materi dan jabatan (Onghokham, 1985). Aktor sentral yang menjadi koruptor kerap kali dijuluki dengan aktor kerah putih, karena memiliki latar belakang intelegensia yang mumpuni serta kekuasaan yang besar. Kenyataan itulah yang membuat kasus-kasus kejahatan korupsi menjadi sukar untuk diungkap dan pelakunya sulit untuk ditangkap oleh aparatur penegak hukum.

Gambaran abstrak terkait kejahatan korupsi di atas dapat terlihat secara konkrit melalui data-data kasus korupsi yang terjadi dua tahun terakhir. Semenjak tahun 2018, kasus kejahatan korupsi telah menembus angka 725 kasus dengan jumlah tersangka 1.667 yang masih diproses hukum. Total kerugian yang diderita oleh negara dari kasus-kasus tersebut ialah sebesar 13,64 triliun rupiah. Maraknya kasus korupsi di tanah air menempatkan negara Indonesia di peringkat ke 4 dalam lingkup Asia Tenggara dan peringkat ke 85 dari 180 negara yang terkorup di seluruh dunia (International, 2020).

Negara dan masyarakat secara luas menderita kerugian yang sangat signifikan dari berbagai praktik korupsi yang terjadi di Indonesia. Berbagai kebijakan strategis yang sedang dijalankan pemerintah turut mengalami stagnasi mengingat anggaran yang telah dialokasikan mengalami defisit. Beberapa di antaranya yaitu kebijakan pembangunan sarana pra sarana (infrastructure development) dan pembangunan manusia (human development) yang berkurang jauh dari segi kualitas maupun kuantitas (Baizatul, 2018). Ujung dari pembangunan yang tidak berjalan sebagaimana mestinya ialah menurunnya pertumbuhan ekonomi nasional yang mengancam kesejahteraan masyarakat secara luas (Pradiptyo, 2017).

Maraknya praktik korupsi yang telah merugikan rakyat Indonesia secara luas merupakan wujud nyata dari lemahnya komitmen negara terhadap pemberantasan korupsi di tanah air. Hal itu dibuk- 
tikan dengan tidak adanya instrumen hukum yang dapat memperkuat Komisi Pemberantasan Korupsi (KPK) sebagai lembaga penegak hukum dalam menjalankan tugas, pokok, dan fungsinya. Undang-undang sebagai instrumen hukum yang mengatur terkait kelembagaan KPK masih sangat rentan untuk diintervensi secara politik melalui mekanisme legislasi biasa. Konsekuensi logis dari lemahnya undang-undang terkait lembaga antirasuah tersebut ialah ketidakpastian hukum, sehingga berujung pada ketidakoptimalan KPK dalam memberantas korupsi yang telah menjamur di Indonesia (Waluyo, 2014).

Ketidakpastian hukum yang menjadi persoalan utama bagi KPK ialah mengenai independensi kelembagaan. Kedudukan KPK sebagai auxiliary state organ tindak pidana korupsi sesuai dengan undang-undang ini" yang bersifat independen kerap kali dikaburkan dengan berbagai instrumen hukum yang berlaku, baik itu putusan Mahkamah Konstitusi hingga peraturan perundang-undangan itu sendiri (Prihantoro, 2010).

Salah satu bukti konkrit dari hal tersebut ialah terbitnya $\mathrm{Pu}$ tusan Mahkamah Konstitusi Nomor 036/PUU-XV/2017 yang menyatakan bahwa KPK tergolong ke dalam rumpun eksekutif, dimana putusan tersebut bertentangan dengan Putusan Mahkamah Konstitusi Nomor 012-016-019/PUU-IV/2006 dan Putusan Mahkamah Konstitusi Nomor 005/PUU-IX/2011 yang menegaskan bahwa KPK termasuk lembaga independen yang berada di luar rumpun kekuasaan manapun. Tidak hanya itu, ketidakpastian hukum terkait independensi KPK secara kelembagaan juga ditemukan dalam taraf undangundang, dimana berdasarkan Undang-Undang Nomor 30 Tahun 2002 tentang Komisi Pemberantasan Tindak Pidana Korupsi menyatakan dalam pasal 3 bahwa "Komisi Pemberantasan Korupsi adalah lembaga negara yang dalam melaksanakan tugas dan wewenangnya bersifat independen dan bebas dari pengaruh kekuasaan manapun." Namun, ketentuan tersebut kembali dirubah dalam pasal 1 ayat (3) Undang-Undang Nomor 19 Tahun 2019 tentang Perubahan Kedua atas Undang-Undang Nomor 30 Tahun 2002 tentang Komisi Pember- 
antasan Tindak Pidana Korupsi yang menyatakan bahwa "Komisi Pemberantasan Korupsi adalah lembaga negara dalam rumpun kekuasaan eksekutif yang melaksanakan tugas pencegahan dan pemberantasan."

Persoalan KPK terkait kelembagaan tidak hanya berkutat pada independensi saja, melainkan menyentuh pula masalah struktur kelembagaan. Lembaga antirasuah tersebut mengalami perombakan struktur kelembagaan yang cukup siknifikan paska diberlakukannya Undang-Undang Nomor 19 Tahun 2019 tentang Perubahan Kedua atas Undang-Undang Nomor 30 Tahun 2002 tentang Komisi Pemberantasan Tindak Pidana Korupsi. Berdasarkan pasal 21 ayat (1) huruf a juncto pasal 37 Undang-Undang tersebut, terdapat organ baru dalam internal KPK yaitu Badan Pengawas yang terdiri dari 5 anggota. Secara umum, keberadaan badan tersebut ditujukan untuk keperluan checks and balances dalam internal KPK saat menjalankan tugas dan kewenangannya, namun keterlibatan Badan Pengawas dalam mekanisme perizinan terkait penyadapan, penggeledahan, dan penyitaan sebagai bagian dari tindakan pro Justitia_sangat tidak tepat, karena KPK dalam melakukan tindakan tersebut bertanggungjawab secara langsung kepada pengadilan.

Berbagai perubahan yang terjadi pada KPK secara kelembagaan sedikitnya mengganggu ritme kerja dari lembaga tersebut dalam menjalankan agenda besar mengenai pemberantasan korupsi di Indonesia (Arrsa, 2014). Penyesuaian kembali yang kerap kali dilakukan oleh seluruh anggota KPK terkait struktur kelembagaan dan alur kerja yang berupaya membuat kinerja dari KPK mengalami stagnasi, sehingga berimplikasi pada ketidakefektifan KPK dalam memberantas kejahatan luar biasa tersebut di tanah air. Padahal penguatan independensi dan stabilisasi KPK secara kelembagaan merupakan modal utama yang harus dimiliki dalam menindak tegas aktor-aktor kerah putih yang telah merugikan bangsa dan negara. Komitmen untuk memperkuat KPK secara kelembagaan sejalan dengan pemikiran Denny Indrayana yang mencetuskan bahwa KPK harus dijadikan constututional state organ yang mendapatkan legiti- 
masi langsung dari Undang-Undang Dasar Negara Republik Indonesia Tahun 1945 (UUD NRI 1945) sebagai konstitusi negara.

Penentuan dasar legitimasi bagi KPK menunjukkan arti penting lembaga tersebut dan komitmen negara dalam memberantas korupsi di tanah air. Semakin tinggi dasar legitimasi bagi KPK, maka semakin urgent pula isu pemberantasan korupsi bagi Negara Indonesia. Pembentukan KPK yang dilandaskan pada Konstitusi menunjukkan dasar legitimasi yang paling kuat, karena konstitusi merupakan sumber hukum tertinggi (Grund norm) (Indrati, 2007). Sementara itu, apabila pembentukan KPK hanya berdasarkan Undang-undang, maka sangat berpotensi untuk diintervensi secara politik melalui proses legislasi (Muttaqin, 2018).

Argumentasi yang menyatakan bahwa pembentukan lembaga pemberantasan korupsi harus berdasarkan konstitusi sebagai dasar legitimasi sangatlah rasional dan logis. Hal itu dikarenakan hakekat dari konstitusi ialah sebagai sumber hukum tertinggi di suatu negeri (The Supreme Law of the Land) (Michelman, 2003). Konstitusi memiliki peranan yang sangat vital bagi negara, karena konstitusi berfungsi sebagai Road Map utama bagi organisasi negara dalam menjalankan kekuasaannya. Materi muatan yang terkandung di dalamnya bersifat prinsip dan fundamental, sehingga keberlakuannya sangat rijid dan sulit untuk dirubah (S, 2005).

Hal itu sejalan dengan pendapat Dahlan Thaib yang mengemukakan ciri-ciri utama dari konstitusi rijid (rigid constitution) yaitu mempunyai kedudukan dan derajat yang lebih tinggi dari peraturan perundang-undangan yang lain dan hanya dapat diubah dengan cara yang khusus atau istimewa, dimana harus memenuhi persyaratan yang berat (Thaib, 2017).

Pencantuman lembaga antirasuah_sebagai salah satu materi muatan konstitusi sudah banyak diimplementasikan di berbagai negara. Setidaknya, terdapat 30 negara di seluruh dunia yang telah membentuk lembaga khusus pemberantasan korupsi yang disandarkan pada konstitusi (Pohan, 2018). Salah satu diantaranya yaitu 
negara Hongkong yang telah membentuk Independent Commission Against Corruption (ICAC) semenjak tahun 1974. Pembentukan lembaga tersebut merupakan amanat langsung dari artikel 6 dan 36 United Nations Convention Against Corruption (UNCAC) yang mewajibkan negara yang meratifikasinya untuk mempersiapkan badan (baik yang sudah terbentuk maupun belum) dengan tugas, pokok dan fungsi utama berupa pencegahan dan pemberantasan korupsi melalui penegakan hukum.

ICAC sebagai institusi penegak hukum yang khusus menangani kejahatan korupsi di Hongkong telah terbukti efektif. Realita tersebut membuat ICAC menjadi role model bagi negara-negara lain di seluruh dunia dalam hal lembaga pemberantasan korupsi yang ideal. Strategi utama dari lembaga tersebut dalam memberantas korupsi ialah berbasiskan tiga ranah yang meliputi pencegahan, penindakan dan pendidikan. Indikator keberhasilan ICAC dalam menangani kasus-kasus korupsi di negara Hongkong dapat terlihat dari Corruption Perceptions Index yang menyentuh angka 76 poin, sehingga membuat Hongkong menjadi negara ke-16 dari 180 negara yang dinyatakan relatif bersih dari korupsi.

\section{Epilog}

KPK merupakan lembaga khusus yang dibuat oleh negara Indonesia untuk memberantas kejahatan korupsi di tanah air. Lembaga tersebut menjadi sangat urgent mengingat kasus demi kasus korupsi yang terjadi di Indonesia tidak mengalami penurunan yang cukup signifikan dari tahun ke tahun. Kestabilan struktur kelembagaan dan independensi menjadi modal utama bagi KPK dalam mengungkap praktik-praktik korupsi yang menjamur untuk menangkap aktor intelektual yang berada di belakangnya. Negara harus menjamin lembaga antirasuah_tersebut dari intervensi politik yang bertujuan untuk melemahkannya secara sistematis. Salah satu bentuk konkrit dari komitmen tersebut ialah dengan memperkuat KPK melalui upaya peningkatan sumber legitimasi dari undang-undang menjadi konsti- 
tusi. Semua itu tidak terlepas dari paradigma kekuasaan yang menyatakan bahwa power tends to corrupt, absolute power corrupt absolutely.

\section{Referensi:}

Akman, Baizatul, dkk, "Pengaruh Korupsi Terhadap Pertumbuhan Ekonomi Di Indonesia", Jurnal Ilmiah Mahasiswa (JIM) Vol.3 No.4 November 2018.

Arrsa, Ria Casmi, "Rekonstruksi Politik Hukum Pemberantasan Korupsi Melalui Strategi Penguatan Penyidik Dan Penuntut Umum Independen KPK", Jurnal RechtVinding Vol. 3 No. 3 Desember 2014.

Direktorat Penelitian dan Pengembangan Deputi Pencegahan Komisi Pemberantasan Korupsi, 2006, Komisi Anti Korupsi Di Luar Negeri, Jakarta.

Djaja, Ermasjah, 2010, Memberantas Korupsi Bersama KPK Edisi Kedua, Jakarta: Penerbit Sinar Grafika.

Frinaldi, Aldri, dan S, Nurman, "Perubahan Konstitusi dan Implikasinya Pada Perubahan Lembaga Negara", DEMOKRASI Vol. IV No.1 Th. 2005.

Indrati, Maria, Farida, 2007, Ilmu Perundang-Undangan 1, Yogyakarta: PT Kanisius.

Indrayana, Denny, 2016, Jangan Bunuh KPK Kajian Hukum Tata Negara Penguatan Komisi Pemberantasan Korupsi, Malang: Intrans Publising.

Michelman, Frank I, "The Constitution, Social Rights, And Liberal Political Justification" I. CON,Vol. 1, No.1, Januari 2003.

Muttaqin, Labib dkk, "Mengkaji Serangan Balik Koruptor Terhadap KPK dan Strategi Menghadapinya", INTEGRITAS Volume 4 Nomor 1 - Juni 2018. 
Onghokham. 1985, Tradisi dan Korupsi dalam Bunga Rampai Korupsi, Cetakan Pertama, Penyunting Muchtar Lubis dan James Scoot, Jakarta: LP3ES.

Pradiptyo, Rimawan, 2017, Dampak Sosial Korupsi, Jakarta: Direktorat Pendidikan dan Pelayanan Masyarakat.

Prihantoro, Angga Martandy, "Eksistensi State Auxiliary Organs Dalam Rangka Mewujudkan Good Governance Di Indonesia (Studi Kelembagaan Terhadap Komisi Pemberantasan Korupsi", Skripsi Fakultas Hukum Universitas Sebelas Maret Surakarta, April 2010.

Thaib, Dahlan, dkk, 2017, Teori Dan Hukum Konstitusi, Jakarta: PT RajaGrafindo.

Transparency International, Corruption Perceptions Index 2019, Berlin 23 Januari 2020.

Waluyo, Bambang, "Optimalisasi Pemberantasan Korupsi Di Indonesia", Jurnal Yuridis Vol. 1 No. 2, Desember 2014.

'Adalah; Buletin Hukum dan Keadilan merupakan berkala ilmiah yang diterbitkan oleh Pusat Studi Konstitusi dan Legislasi Nasional (POSKO-LEGNAS), Fakultas Syariah dan Hukum UIN Syarif Hidayatullah Jakarta. Penasehat: Prof. Dr. H. Abdul Ghani Abdullah, SH., Prof. Dr. H. A Salman Maggalatung, SH., MH. Tim Redaktur: Indra Rahmatullah, Mara Sutan Rambe, Muhammad Ishar Helmi, Erwin Hikmatiar, Fathuddin, Nurrohimyunus. Penyunting: Latipah Nasution, Siti Nurhalimah, Siti Romlah. Setting \& Layout: Imas Novita Juaningsih. 